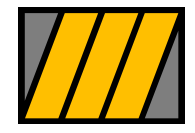

EsCUeLA DE NEGOCIOS Universidad Torcuato Di Tella centro de investigación en finanzas

Documento de Trabajo 03/2010

\title{
International Government Debt
}

\author{
Ugo Panizza \\ UNCTAD and the Graduate Institute, Geneva
}

and

Federico Sturzenegger

UTDT and Banco Ciudad

and

Jeromin Zettelmeyer

IMF and EBRD 


\title{
International Government Debt
}

\author{
Ugo Panizza \\ Federico Sturzenegger \\ Jeromin Zettelmeyer ${ }^{*}$
}

\section{$1 \quad$ Introduction}

The objective of this chapter is to present a non-technical survey of the modern literature on international government debt. In doing so, it aims to match predictions made by theoretical models with the existing empirical evidence and to identify the models that best explain the real world experience of sovereign debt and sovereign default.

Although this chapter focuses on the experience of the last 40 years, sovereign debt and sovereign default have been with us for a very long time. Winkler (1993) reports that the first documented default goes back to the fourth century BC, when several Greek municipalities defaulted on the Delos Temple. Reinhart and Rogoff (2009) document eight centuries of sovereign borrowing and default episodes. Sturzenegger and Zettelmeyer (2007) review the experience of the last 200 years and show that lending booms are almost invariably followed by default waves.

Some readers may find the title of this chapter unusual. Academic and policy discussions tend to focus on "external" (as opposed to "domestic") government debt and not "international" government debt. The difference is that the latter refers to debt issued in international markets and the former to debt owed to non-residents. We prefer "international" to "external" because the actual data collected by statistical agencies' as "external" debt. in fact, measure something which is much closer to our definition of international debt (Box 1). This is a consequence of the fact that, when international debt is tradable, it is virtually impossible to track whether it is owned by non-residents or residence. Recently, there have been attempts to supplement this data with data on domestically issued government debt, which can interact with international debt in important ways (see Borensztein, Levy Yeyati, and Panizza, 2006, Panizza, 2008,

\footnotetext{
* Ugo Panizza United Nations Conference on Trade and Development and the Graduate Institute, Geneva (ugo.panizza@unctad.org). Federico Sturzenegger Universidad Torcuato di Tella and Banco Ciudad (fsturzen@utdt.edu). Jeromin Zettelmeyer International Monetary Fund and European Bank for Reconstruction and Development (zettelmj@ebrd.org). Chapter prepared for the Elsevier Encyclopedia of Financial Globalization. We would like to thank, without implication, Stijn Cleassens and Sergio Schmukler for inviting us to write this paper and Mackie Bahrami for helpful comments and suggestions. Some portions of this article draw on Panizza, Sturzenegger, and Zettelmeyer (2009). The views expressed in this chapter are the authors' only and need not reflect, and should not be represented as, the views of any of the institutions that the authors are affiliated with
} 
2010, Reinhart and Rogoff, 2009). The coverage of this data for the developing world remains patchy (Box 2).

The rest of the chapter is organized as follows. Section 2 describes how the levels and structure of international government debt have evolved during the last 40 years. It presents some broad regional trends in international government debt; and describes the recent switch from international to domestic government borrowing. Section 3 reviews economic theories of sovereign (government) debt, whose defining characteristic is the impossibility of enforcing repayment. At the center of this literature is the question how governments can issue debt internationally in spite of this enforcement problem. Section 4 tries to match the theory with the data. While economic theory has succeeded in rationalizing the existence of sovereign debt, traditional models often have implications that are inconsistent with basic facts. In particular, sovereign debt theories usually predict countercyclical borrowing (countries borrow in bad times and repay in good times), while actual borrowing by developing countries is often procyclical. They also predict that defaults either never happen or take place in good times, while most defaults tend to happen during crises. The section concludes by discussing recent attempts to reconcile the theory with the evidence, and describes how defaults are resolved. Section 5 discusses the role of debt structure and presents two alternative views on the relationship between debt structure and crises. According to the first view there is a causal relationship between debt structure and debt crises. Thus, changes in debt structure can contribute to improving debt sustainability in developing countries. According to the second view, a poor debt structure is just a reflection of deeper institutional problems. To improve its debt structure, countries must address these. Section 6 concludes.

\section{Trends}

The primary source of data on international government debt in low and middle income countries is the World Bank's Global Development Finance (GDF) dataset. Although the GDF data are comprehensive and extremely useful, there are two issues with this dataset.

The first has to do with the definition of external debt (see Box 1). GDF officially reports external debt. However, conversations with users and data suppliers (GDF reports data obtained from debtor countries) suggest that most data refer to what we define as international government debt. Consequently, in what follows, we will refer to GDF data as international government debt data. 
The second issue refers to our ability to identify short term international government debt. GDF reports data on long term debt (defined as debt having an original maturity of more than one year) and short term debt. It also breaks down its debt data between private (debt owed by the private sector) and public and publicly guaranteed (PPG) debt. However, this breakdown is only provided for long term debt. Since it is impossible to obtain a break down for short term debt, we cannot describe the evolution of total international government debt, and need to focus on total long-term international government debt. Fortunately, short term government debt tends to be domestic, so ignoring international short term government debt is not a big problem for most countries.

At the beginning of the 1970s, developing countries had relatively low levels of external debt. In 1970, the total long-term international debt of developing countries stood at approximately $\$ 45$ billion, or about 7 percent of these countries' total GDP (Figure 1). Debt started growing rapidly after the 1973 oil shock and then again after the debt crisis that started with Mexico's default in 1982. By 1987, the total long-term international debt of developing countries was close to $\$ 900$ billion, corresponding to 30 percent of this group of countries' total GDP.

The increase in international debt was also accompanied by a change in debt composition. In the early 1970s, most international government debt was due to bilateral or multilateral official creditors (in 1970, 70 percent of total international government debt was due to official creditors and nearly 80 percent of this official debt was due to bilateral creditors). In 1987, more than 50 percent of total long-term international government debt was due to private creditors (mostly international banks) and about 25 percent of the total (50 percent of official debt) was due to multilateral institutions.

While the dollar value of total debt kept increasing until 2004 (when it peaked at $\$ 1.5$ trillion), the average debt to GDP ratio of developing countries stabilized at around 28 percent in the first half of the 1990s and then started declining rapidly in the new millennium, bottoming out at 9.5 percent of the group's GDP in 2007. The reduction in external debt levels was accompanied by three trends in debt composition. The first had to do with the composition of official debt, which witnessed a decline in bilateral lending and an increase in multilateral lending. The second was related to the composition of external debt and to the increasingly important role of bonded debt. In the 1980s, about two thirds of the developing countries' debt owed to private creditors took the form of syndicated bank loans and only 7 percent took the form of international bonds (the remaining 25 percent did not fit either of these categories). By 2008, nearly 70 percent of debt owed to private creditors took the form 
of bonds and only 25 percent syndicated bank loans (this reversal in debt composition was the result of the Brady exchanges of the early 1990s. Box 3).

The third trend had to do with the composition of the total (domestic and international) government debt of developing countries. In 1995, international debt represented more than 50 percent of the total debt of these countries; by 2007, the share of international debt was well below 25 percent (Figure 2). This retreat from the international borrowing market had important implications for economic policy.

Most international government debt issued by developing countries is denominated in foreign currency, a phenomenon that Hausmann (1999) and Eichengreen and Hausmann (1999) labeled as "original sin." The presence of foreign currency debt leads to currency mismatches that greatly complicate the conduct of macroeconomic policies. The financial crises of the second half of the 1990s focused the attention of economists on several issues related to debt composition and currency denomination (see, among others, Krugman, 1999). More recently, several observers have argued that currency mismatches are no longer a problem because many countries are now able to issue internationally in domestic currency. In this view, "redemption" from original sin is one of the reasons why developing countries are now able to conduct countercyclical policies. Hausmann and Panizza (2010), however, look at this claim and find limited traction for the "redemption" hypothesis. ${ }^{1}$ This said, it is true that a larger share of total (international and domestic) government debt is denominated in local currency today than was the case ten years ago. Particularly Latin America has made progress in this regard.

Some these trends will be affected by the 2007-09 international financial crisis, which hit most low and middle income countries in the second half of 2008. The combination of output stagnation or declines with sharp rises in deficits will lead to jumps in the ratio of debt to GDP - although less so than in advanced countries, primarily because most developing countries ran smaller fiscal deficits in the crisis. Whether or not this reversal will be transitory or permanent remains to be seen, and will depend in part on the vigor of post-crisis growth. In

\footnotetext{
${ }^{1}$ They show that very few countries have been able to issue internationally in their own currency and that the participation of foreign investors in the local bond markets is still limited. They conclude that the reduction in currency mismatches and the consequent ability to conduct macroeconomic policies was due to "abstinence" (i.e., the retreat from the international bond market documented in Figures 1 and 3) and not redemption. In 2001, only 0.8 percent of all bonded international debt instruments issued by developing countries were denominated in the currency of the issuing country (Eichengreen, Hausmann, and Panizza, 2005). By 2008, the share of international bonded debt issued by developing countries and denominated in the currency of the issuer had increased to 4.1 percent (Hausmann and Panizza, 2010).
} 
other respects, the crisis is likely to boost existing trends, particularly the trend toward domestically issued and local currency debt.

\section{Looking beyond averages}

The trends highlighted in Figures 1 and 2 mask an important cross-country heterogeneity. Given that these figures are computed as weighted averages, they assign a greater weight to the largest economies. For instance, four countries (Brazil, China, India, and Russia, the "BRICs") represent nearly 40 percent of the total output of the developing and emerging world and 8 countries (the BRICs plus Argentina, Korea, Mexico, and Turkey) represent 60 percent of the total output of developing and emerging market countries. It is thus instructive to break down the sample across geographical areas and describe both weighted and simple averages.

These differences show that smaller countries have debt ratios which are substantially higher than the debt ratios of the larger economies and that the difference between small and large countries has been increasing over time (Table 1). Until the first half of the current decade, the weighted average of total long-term international public debt of developing countries stood at 2-3 times its simple average (in 2000-2004, the figures were 21.1 percent and 59.8 percent, respectively). By 2008, the simple average was almost 4 times the weighted average (40.7 percent versus 11.3 percent). This indicates that the declining debt trend documented in Figure 1 is partly due to the behavior of the largest developing and emerging economies. If we focus on total external debt (public and private), the difference between weighted and simple averages is roughly about 1 to 2 (58.4 percent versus 25.8 percent). This would suggest that a far greater percentage of the external debt belonging to larger countries is owed by private borrowers. Large economies also have more debt with private creditors (about 50 percent of the weighted average of total external public debt in 2005-2008) and smaller economies have more debt with official creditors (more than 75 percent of the simple average of total external public debt).

If we look across regions, we find that, when measured as weighted averages, current levels of public international debt are particularly low in East and South Asia and in East Europe and Central Asia (this last region, however, has high levels of international debt owed by private borrowers) and much higher in the Middle East and North Africa and Sub Saharan Africa regions. Latin America had relatively high levels of debt in the mid 1990s, but reduced dramatically its indebtedness in the second half of the first decade of the new millennium (sub Saharan Africa more than halved its debt thanks to the HIPIC initiative). Latin America, 
South Asia, East Asia and sub Saharan Africa are also the regions which show the largest difference between the simple and weighted averages, indicating that large countries in these regions have debt levels which are markedly lower than the debt levels of smaller countries.

Finally, there are large regional differences in the composition of international public debt. Most of the international public debt of South Asia, Sub Saharan Africa, and East Asia is due to official creditors (if we focus on the simple average, the share of international public debt owed to official creditors ranges between 80 and 90 percent; if we focus on the weighted averages the fraction ranges between 60 and 80 percent). Whereas, the share of debt due to official creditors is much lower in East Europe and Latin America. If we consider the weighted average, only 30 percent of the international public debt of Latin American countries is owed to official creditors. Most of the remaining 70 percent which is owed to private creditors takes the form of sovereign bonds.

\section{The theory of external government debt}

What makes sovereign debt different from private debt is that there is no well defined procedure for enforcing sovereign debt contracts and for managing sovereign defaults. If a private borrower does not repay its debts, creditors have a well defined claim on the borrower's assets. In the case of sovereign debt, the legal recourse available to creditors has limited applicability and uncertain effectiveness. The objective of this section is to provide a brief introduction to the economic theory of sovereign debt (for more detailed surveys see Eaton and Fernandez, 1995, Kletzer, 1994, and Panizza, Sturzenegger, and Zettelmeyer, 2009).

The principle of sovereign immunity, which derives from the equality of sovereign nations under international law, states that sovereigns cannot be sued in foreign courts without their consent. However, sovereign immunity does not grant full protection to sovereign debtors, as a sovereign can decide to waive its immunity and agree to submit to the authority of a foreign court in the event of a dispute. ${ }^{2}$ But even in these cases, sovereign debt remains difficult to enforce because creditors' ability to collect is limited by the fact that only assets located outside the sovereigns' borders can be legally attached, and countries tend to hold most of their assets within their borders. ${ }^{3}$

\footnotetext{
${ }^{2}$ The principle of sovereign immunity in debt disputes has been progressively relaxed since the 1950s (Panizza, Sturzenegger, and Zettelmeyer, 2009).

${ }^{3}$ Central bank reserve assets placed with the Bank for International Settlements are not attachable.
} 
Given this limited ability to enforce sovereign debt contracts, why do lenders lend and why do sovereigns repay? How can a market in which contracts cannot be enforced exist? Eaton and Gersovitz (1981) address these questions by building a model in which creditors have no ability to enforce repayment whatsoever and their only means of punishing defaulters is the denial of future credit. Under the assumption that debtors want to smooth consumption but cannot store their output, they show that, under certain conditions, the threat of permanent exclusion from future credit is a sufficient condition for repaying. In the model of Eaton and Gersovitz the maximum amount of sustainable debt is positively related to the variance of output and the country's preference for smoothing consumption.

The paper by Eaton and Gersovitz became the target of three types of criticism, all of which were anticipated by the authors. The first related to the assumption that default on repayment can be punished by denying the borrower future credit. The critics' main contention was that the threat of a permanent embargo on future lending is not credible, because it hurts potential future lenders too, and because once a borrower defaults, his ability to pay increases, thus giving incentives to creditors to resume lending.

The second criticism concentrated on the assumption that borrowing from international lenders is the only way in which countries can smooth consumption. Bulow and Rogoff (1989a) showed that if a country can purchase an insurance contract that delivers payments in low output states, the threat of credit denial loses its bite entirely.

The final criticism relates to the fact that reputation can only sustain an equilibrium with positive debt if there is a motivation (such as the desire to smooth consumption in response to output shocks) which makes a country wish to the credit markets in the indefinite future. In other words, reputation cannot sustain debt motivated by impatience to consume (implying a point at which the country most repay without every borrowing again) or by the need to accumulate capital (Eaton, Gersovitz, and Stiglitz, 1986).

Successive authors have addressed these criticisms, with varying success. A first group of authors made the assumption that the possibility of punishments would have a negative effect on the defaulter's trade flows (Sachs and Cohen, 1982, Bulow and Rogoff, 1989b, Fernandez and Rosenthal, 1990). ${ }^{4}$ But again, this type of punishment is credible only if, besides harming the defaulter, it also benefits the creditor. If blocking trade credit or imposing a trade embargo also hurts the creditor country, the threat is not credible and cannot sustain positive lending.

\footnotetext{
${ }^{4}$ Such punishment could block trade payments through seizure outside the country's borders or via the denial of trade credit.
} 
A second group of authors argued that positive lending can be sustained because insurance contracts á la Bulow-Rogoff are either not feasible or not optimal from the borrower 's point of view. Those who argue that such contracts are not feasible point out that financial institutions may not be able to commit to payments to defaulters, because past lenders could attempt to interfere with such payments (Cole and Kehoe, 1995, Eaton, 1996, and Kletzer and Wright, 2000). Perhaps more interestingly, Wright (2002) shows that there are conditions in which banks will find it optimal to collude to punish defaulters. This can lead to an equilibrium with positive lending even in a setting which allows for insurance contracts á la Bulow-Rogoff and assumes that the threat of credit denial is the only punishment for defaulters. Amador (2003) obtains a similar result by developing a political economy model, in which myopic governments, that are afraid of losing power, overborrow but do not default because they want to retain access to capital markets in case they return to power.

While the classic theory of sovereign debt focuses on the actions of non-residents, there is a more recent class of models that focuses on the domestic effects of the default. Because of these broader implications, positive lending can be sustained even when creditors have no way to punish defaulting countries. This could be the case, for example, if defaults are interpreted by economic agents as bad news for either the sovereign or the economy. Cole and Kehoe (1998) assume two types of governments: "honest” governments that always repay, and "normal" governments which sometimes do not repay. They show that if the government only deals with lenders, the Bulow-Rogoff result applies and no borrowing can be sustained by "normal" governments. If, however, there is another relationship in which the government's partners have incomplete information about the government's true type, the government may have the incentive not to default, because defaulting would damage the government's reputation vis a vis this second party. ${ }^{5}$

\section{$4 \quad$ Evidence on external borrowing and default}

In most theoretical models of sovereign debt, countries borrow in order to transfer income from good to bad states of the world. While these models predict that debt flows should be countercyclical, there is evidence that private lending to sovereigns tends to be procyclical

\footnotetext{
${ }^{5}$ A related class of papers focuses on the information content of default with respect to the underlying structure of the economy (Sandleris, 2006; Catão and Kapur, 2006; Catão, Fostel, and Kapur, 2007). Mendoza and Yue (2008), instead, focus on the domestic costs of defaults. By assuming that a sovereign default limits the ability of private agents to obtain the working capital necessary to buy imported inputs, they show that defaults will lead to an inefficient reallocation of labor and have a negative effect on total factor productivity.
} 
(developing countries tend to borrow more in good times; see Levy Yeyati, forthcoming). There are three possible explanations for procyclical lending. The first focuses on market failures and argues that procyclicality is driven by the fact that during recessions developing countries lack access to international credit (Gavin and Perotti, 1997). The second explanation concentrates on political failures and suggests that procyclicality is the result of conflict across various interest groups, wasteful spending pressures, or the presence of corrupt politicians (Tornell and Lane, 1999; Talvi and Végh, 2005; Alesina, Campante, and Tabellini, 2008). A third class of explanations relates to the nature of the output shock. While models in the spirit of Eaton and Gersovitz (1981) assume transitory output shocks, Aguiar and Gopinath (2006), and Rochet (2006) show that models with persistent shocks can generate procyclical borrowing even in the absence of political or capital market imperfections.

While the empirical evidence suggests that defaults tend to happen during periods of low economic growth (Levy Yeyati and Panizza, forthcoming, Tomz and Wright 2007), the simplest sovereign debt models predict that we should never observe defaults during bad times because countries are only meant to repay during good times. By contrast, the evidence of countercyclical defaults is consistent with the predictions of more sophisticated models that assume persistent shocks (Aguiar and Gopinath, 2006, and Rochet, 2006). However, even these more sophisticated models greatly underpredict the probability of default episodes (Aguiar and Gopinath, 2006). This failure may be due to the fact that while these models tend to focus on domestic factors as driving defaults, while default episodes can also be caused by exogenous changes in global credit cycles (for instance by global "Sudden Stop" episodes as described by Calvo, 2005). The idea that in addition to domestic factors, defaults are influenced by the behavior of creditors and international capital markets is consistent with the fact that default episodes tend to happen in clusters, typically after periods of market bonanza.

Defaults are almost never total. When a country cannot repay its debts, it enters in a negotiation process with its creditors and the outcome of this process determines the haircut involved in the debt restructuring process. Most default episodes involve official (bilateral and multilateral) creditors and private creditors. Whereas negotiations with official creditors usually take place within the "Paris Club," currently, there is no established mechanism for negotiations between a sovereign state and its private creditors.

In the 1970s and 1980s, the creditors of emerging market sovereigns tended to be banks and renegotiations were conducted through "bank advisory committees” consisting of representatives of the major bank creditors. After the Brady deals of the 1990s, emerging market countries started to borrow by issuing bonds in the international capital markets 
(mostly New York and London). The presence of a large number of bondholders with different size and institutional characteristics (from pension funds to individual retail holders) led to a situation in which creditors could not agree to any unified representation.

In the late 1990s and the first years of the new millennium, there was a widespread belief that these institutional changes would have negative implications. The argument was that the presence of a large number of heterogeneous bondholders would make coordination impossible and lead to protracted and litigious debt restructurings and substantial deadweight losses. This would increase the cost of debt crises for both creditors and debtors without having any ex-ante benefit in terms of expected willingness to pay. These preoccupations motivated several policy initiatives aimed at mitigating collective action problems in sovereign debt restructurings. Proposals ranged from issuing bonds with collective action clauses to establishing an international bankruptcy mechanism for sovereigns. ${ }^{6}$

Despite the attention dedicated to these issues, the switch from syndicated bank loans to bonded debt does not, in fact, seem to have affected the costs of debt crises and made their resolution more difficult. ${ }^{7}$ Borensztein, Levy Yeyati and Panizza (2006) and Benjamin and Wright (2008) show that the average default episode in the 1970s and 1980s was substantially longer than the average default episode in the 1990s. ${ }^{8}$ Among the main bond restructuring episodes since 1998 studied by Sturzenegger and Zettelmeyer (2007) only one (Argentina) lasted more than two years. Furthermore, in most of these recent cases (Argentina is again the main exception) creditor participation was above 90 percent, and both pre-and post restructuring litigation has remained rare. There is also no evidence that recent bond restructurings have resulted in more "coercive" creditor treatment, that the practice of take-itor-leave it offers has shifted bargaining power to debtor countries (Enderlein, Müller, and Trebesch, 2008), or that the number of creditors or the type of instrument is correlated with the duration of the restructuring process (Trebesch, 2008). Finally, estimates of creditor losses on sovereign debt indicate that debt restructurings conducted through bond exchange offers since 1998 did not, on average, involve higher (if anything, slightly lower) haircuts

\footnotetext{
${ }^{6}$ See Barry Eichengreen and Richard Portes (1995); Group of Ten (1996); Anne Krueger (2001); Sean Hagan (2005); and Rogoff and Zettelmeyer (2002) for a survey. Theoretical analyses of these proposals include Eichengreen, Kletzer and Ashoka Mody (2003); Jeanne (2004); Patrick Bolton and Jeanne (2007); Andrew Haldane et al. (2004); Pitchford and Wright (2007); and Sergi Lanau (2008).

${ }^{7}$ For a theoretical discussion of why the feared increase in the cost of debts crises did not materialize see Bi, Chamon, and Zettelmeyer (2008).

${ }^{8}$ The duration of a default episode is usually measured as the amount of time between the moment in which a country stops servicing its debt (sometimes credit rating agencies allow for a short grace period) and the moment in which debt restructuring is completed. Post-restructuring litigations are not usually included in the computation of the length of the default episode.
} 
than the negotiated Brady deals, which put an end to the debt crisis of the 1980s (Cruces and Trebesch, 2010). ${ }^{9}$

In addition to the literature on the cyclical properties of defaults, there are numerous papers which study the determinants of sovereign defaults. Broadly speaking, these papers can be divided into two groups. The objective of the first group is to identify a series of early warning indicators that can be used to predict default episodes. Papers in this tradition, which date back to the work of Cline (1984) and McFadden et al. (1985), have found that the probability of a sovereign default is positively associated with higher levels of total debt and higher shares of short-term debt, and negatively associated with GDP growth and the level of international reserves. Defaults are also related to more volatile and persistent output fluctuations, less trade openness, and weaker institutions (Catao and Sutton, 2002, Manasse, Roubini and Schimmelpfennig, 2003, Van Rijckeghem and Weder, 2004, Kohlscheen, 2005, and Pescatori and Sy, 2007). A second group of papers tries to identify why some countries seem to be structurally more prone to default than others, and particularly on the role of debt structure. These papers form part a broad recent literature on debt structure, which we briefly discuss in the final section of this chapter.

\section{Debt structure and debt crises}

Until recently, work on government debt (either domestic or external) focused on the total level of debt with limited attention being given to the role of debt structure. However, the crisis of the 1990s showed the importance of debt composition and highlighted the risks associated with short-term and foreign currency borrowing.

The debt level, often scaled by the country's GDP, is one of the most commonly used indicators of a country's ability to face its obligations. Since developing countries suffer from many debt crises, one would expect them to have much worse debt to GDP ratios than those of the advanced economies. However, this is not the case (Borensztein, Levy Yeyati, and Panizza, 2006). On average, developing countries do not have levels of public debt that are substantially higher than those of the advanced economies. Take, for instance, the case of Japan which has a public debt well above 150 per cent of the country's GDP. And yet, the Japanese debt is considered to be safe and pays interest rates which are close to zero. Concurrently, developing countries often face debt crises with debt levels which are as low as 30 per cent of GDP (Reinhart, Rogoff, and Savastano, 2003). The same holds true if one

\footnotetext{
${ }^{9}$ Cruces and Trebesch (2010) estimate that the average haircut in the Brady deals was about 53 percent and the average in recent default episodes was approximately 37 percent.
} 
focuses on external debt. The United States has an enormous external debt, much larger than that of the average developing country. And yet, while there have often been worries about possible depreciations of the US dollar, US government debt has traditionally been viewed as safe. Even today, after rises in government to GDP ratios of over 30 percentage points in countries such as the US and UK, treasury bonds in these countries carry a AAA credit rating and pay low interest rates.

There is empirical evidence that debt structure plays a role in explaining why developing countries suffer debt crises even at moderate levels of debt. For instance, the literature on "original sin" has focused on the currency composition of external debt and argued that the presence of foreign currency debt plays a role in reducing debt sustainability (Eichengreen and Hausmann, 1999, Eichengreen, Hausmann, and Panizza, 2003). Along similar lines, Detragiache and Spilimbergo (2001) show that the presence of short term debt is correlated with the probability of a debt crisis. Focusing on currency and maturity composition helps explaining why developing countries face frequent debt crises while a country like the United States faces no problems sustaining its debt. The difference is not due to where they borrow and how much they borrow, but to the fact that the US can borrow long-term in its own currency and that developing countries have traditionally borrowed either short term or in foreign currency.

While the correlation between debt structure and debt crises is fairly uncontroversial, economists are divided on the question of the causes of unfavorable debt structure and whether something can be done to alter the debt structure of developing and emerging market countries. There are essentially two views in the policy and academic debate (Borensztein et al., 2004). On the one hand, there are those who argue that the debt structure is not necessarily correlated to institutions and policies. According to this view, a country's inability to borrow in its own currency is mostly due to network externalities and historical accidents which have persisted (Eichengreen, Hausmann, and Panizza, 2005). Many proposals for reforming the international financial architecture are rooted in this view. Proponents argue that the existing situation can be changed and that debt sustainability can be improved through the creation of new instruments and new institutions (see, among others, Eichengreen and Hausmann, 2005; Borensztein and Mauro, 2004).

On the other hand, there are those who focus on the role of policies and institutions and conclude that the status quo is just a reflection of a more fundamental credibility gap. Reinhart, Rogoff, Savastano (2003) thus argue that developing countries are "debt intolerant" because they lack the institutional set up to sustain even moderate levels of debt. According to 
this view, poor institutional quality affects debt sustainability because it leads to a misallocation of resources (possibly through corruption or just simple waste) and to bad policies. In turn, bad policies reduce ability to pay because they are associated with high macroeconomic volatility and low economic growth. Therefore, a bad debt structure is not the fundamental cause of debt crisis; it is simply a symptom of a deeper domestic problem (Burger and Warnock, 2006, Guscina and Jeanne, 2006, and Claessens, Klingebiel, and Schmukler, 2007, find a correlation between debt composition and the quality of policies and institutions). With respect to policy prescriptions, this view maintains that the only way in which developing countries will be able to sustain higher levels of debt is by addressing the more fundamental problems, and in particular, by improving their institutions and legal frameworks.,In the meantime, developing countries should maintain relatively low levels of debt. Whether or not making countries fit for better debt structure and higher borrowing capacity needs to take a long time is a subject of debate. On the one hand, institutions are persistent, and hard to reform. On the other, there is plenty of evidence suggesting that countries that undertake decisive reform and build credibility over reasonably short periods of time - that is, a decade rather than a lifetime. Examples include de-dollarisation experiences in countries such as Mexico, Israel, and Poland.

\section{Conclusions}

For at least three decades, economists have been struggling with the question of why are borrowers willing to repay (and lenders willing to lend) even in the absence of enforceable property rights. For a much longer period, policymakers have focused on the cost and causes of debt crises and tried to devise mechanisms that can reduce the frequency and consequences of such crises. These are closely linked issues. It is because strategic defaults may lead to costly crises that lenders repay. This connection between the cost of debt crises and willingness to repay is a key challenge for policies aimed at reducing the ex post costs of debt crises.

In spite of a large body of research, the precise nature of the costs of default remains vague and the costs are hard to quantify. Capital markets do not seem to impose long-lasting punishment on defaulters and the evidence on the trade cost of default is far from being definitive, especially because there is no evidence on the channels through which a default may reduce trade. Even the relationship between default and GDP growth has been called into question as it is not sure whether defaults cause output drops or the other way around. 
Answering to these and many other questions is likely to require a better understanding of the domestic costs of default. More work may be needed on the possibly long lasting effects of default on institutions and credit culture which might be hard to capture with standard econometric exercises. There also needs to be more work on the incentives of domestic policymakers. Self-interested policymakers may try to avoid defaults even at increasing economic cost as they are afraid that a default episode will increase the probability of a political turnover. But the may also decide to postpone default to signal that the default (if it finally happens) is unavoidable and not strategic, and hence does not merit punishment (in line with Grossman and Van Huyck's (1988) model that assumes that "excusable" defaults carry not costs). But even if they point in the right direction, these explanations raise new questions: why is it that politicians often lose their jobs after defaults; and what are the channels through which "strategic" defaults lead to higher costs than "excusable” ones? As sovereign debt and debt crises returns to the center of the public policy agenda in the aftermath of the financial crisis of 2007-09, these questions will be with us for time to come. 


\section{Box 1: International, External, and Domestic Government Debt}

There are three possible ways to define external debt. The first focuses on the currency in which the debt is issued (with external debt defined as foreign currency debt). The second focuses on the residence of the creditor (external debt is debt owed to non-residents). The third focuses on the place of issuance and the legislation that regulates the debt contract (external debt is debt issued in foreign countries and under the jurisdiction of a foreign court).

The first definition does not seem appropriate because several countries issue foreign currency denominated debt in the domestic markets and have recently started to issue domestic currency denominated debt in international markets. Moreover, this definition is problematic for countries that adopt the currency of another country ${ }^{10}$

The second definition is the one which is officially adopted by the main compilers of statistical information on public debt. ${ }^{11}$ This definition makes sense from a theoretical point of view because it focuses on the transfer of resources between residents and non-residents, it allows to measure the amount of international risk sharing and the income effects of variations in the stock of debt, and to evaluate the political cost of a default on public debt. However, this definition is almost impossible to apply in the current environment where a large share of the external debt due to private creditors takes the form of bonds. ${ }^{12}$

As a consequence, most countries end up reporting figures based on the third definition which focuses on the place of issuance and jurisdiction that regulates the debt contract. This is not a problem, per se, the problem is that the information is misleading because it does not measure what it promises to do (i.e., transfer resources from non-residents to residents).

This discussion would be irrelevant if there were a close match between the place of issuance and the residency of the ultimate holder, as it used to be the case in the past. However, there is anecdotal evidence that more and more international investors are entering the domestic

\footnotetext{
${ }^{10}$ This does not mean that countries should not report information on the currency composition of their external debt. In fact, such information is a key factor for evaluating a country's vulnerability to currency mismatches and potential responses to a debt crisis.

${ }^{11}$ The External Debt Statistics: Guide for Compilers and Users jointly published by the BIS, Eurostat, IMF, OECD, Paris Club, UNCTAD, and the World Bank states that: "Gross external debt, at any given time, is the outstanding amount of those actual current, and not contingent, liabilities that require payment(s) of principal and/or interest by the debtor at some point(s) in the future and that are owed to non-residents by residents of an economy."

${ }^{12}$ IMF (2006, 2007) reports that while debt sustainability analysis exercises claim to use an external debt definition based on the residency of the ultimate holder, for the majority of countries there is no information on the residency of the ultimate holders and hence external debt is set to be equal to debt issued in the international market.
} 
markets of developing countries and that domestic investors often hold bonds issued in international market (even though this anecdotal evidence seems to overplay what really happens, Hausmann and Panizza, 2010).

As a consequence, the third definition, which classifies as external all debt issued under foreign law, seems preferable. While the second definition is the one which is theoretically correct, a definition based on jurisdiction is feasible and does not give misleading information on who are the supposed holders of a country's debt. 


\section{Box 2: Domestic and International Government Debt. The Quest for better data}

Most research on the debt problems of developing and emerging countries focuses on external debt. This reflects the fact that much of economic theory has looked at the debt of sovereigns as national debt, owed to non-residents, as opposed to public debt, which can be owed to domestic private individuals and non-residents alike (see section 3). However, the focus on external debt is problematic for several reasons. First, in recent years several countries adopted aggressive policies aimed at retiring public external debt and substituting it with domestically issued debt. Second, most countries have no way of knowing who holds their debt (Box 1). Third, in countries with an open capital account, currency and maturity mismatches are the real source of vulnerabilities. Fourth, several external debt crises originated in excessive accumulation of domestic debt (Reinhart and Rogoff, 2009). ${ }^{13}$

For all these reasons, empirical research would do well to pay more attention to domestic debt. However, analysis of public debt in developing countries continues to focus on external debt - essentially because we have little good data on domestic debt. ${ }^{14}$

Recent attempts at collecting data on the composition and level of total public debt for various subsets of developing countries have made some inroads. These include Jeanne and Guscina (2006), Cowan, Levy Yeyati, Panizza, and Sturzenegger (2006), Christensen (2005), IMF (2006), Jaimovich and Panizza (200X), Panizza (2008) and Reinhart and Rogoff (2009). Jeanne and Guscina (2006) and Cowan et al. (2006) have a similar (albeit, not identical) structure and report detailed data on debt levels and composition, focusing on both external and domestic debt. Jeanne and Guscina cover 19 emerging market countries and Cowan et al. cover 23 countries located in Latin America and the Caribbean. Both datasets aim at covering the 1980-2004 period but have missing information for some countries in the 1980s and early 1990s. Christensen (2005) and IMF (2006) only cover domestic debt. The first dataset focuses on a sample of 27 Sub-Saharan Countries over the period 1980-2000, and the second on a sample of 66 low income countries over the 1998-2004 period. Jaimovich and Panizza (2009) and Panizza (2008) builds a dataset on public debt of up to 130 countries for the period 19902006) which aims at capturing both the domestic and external components of public debt, no matter who the holders are. Reinhart and Rogoff (2009) assemble long time series (going

\footnotetext{
${ }^{13}$ The Mexican crisis of 1994/1995 is a good illustration of the dangers of different types of debt and of the importance of the structure of domestic debt, Borensztein, Levy Yeyati, and Panizza (2006)

${ }^{14}$ IMF-World Bank (2004) claim that "the perception, that domestic debt does not play an important role in low income countries, may have been partly the result of weak data availability" (p. 31). For many countries, we do not even have information on the level of total public debt (Jaimovich and Panizza, 2006).
} 
back several centuries) on domestic debt for a sample of up to 16 countries and present the most comprehensive attempt of looking at the long-run evolution of total public debt. 


\section{Box 3. The Brady Deals as catalysts for the EM Bond Market}

In 1970, the international debt of developing countries was low and almost totally with official creditors. This is not surprising given that capital flows from rich to poor countries collapsed after the wave of sovereign defaults that followed the 1929 crash (Flandreau, Gaillard, and Panizza, 2010). Sovereign international debt started growing rapidly in the 1970s when international banks faced the need to recycle the petrodollars of the members of the Organization of the Petroleum Exporting Countries (OPEC). When the US increased its policy rates, and a global recession hit the developed and developing world, several countries which had gone in a borrowing binge in the previous period of abundant credit and low interest rates started having problems facing their debt obligations. The wave of defaults began with the Mexican default of August 12, 1982 and culminated in February 1987 when Brazil declared a debt moratorium. More than 40 countries defaulted on their debt between 1982 and 1987. This period also witnessed several failed attempts to restructure the defaulted debt. In the late 1980s, several large international banks admitted that a substantial fraction of the loans that they had extended to developing countries was either in default or nonperforming (Arslananp and Henry, 2004).

In 1989, US Treasury Secretary Nicholas Brady proposed a debt exchange plan aimed at increasing the maturity and reducing the principal and interest on the defaulted debt. Banks and countries that participated in the Brady Plan received a \$25 billion credit enhancement package and during the 6 years that followed the launch of the plan more than 200 billion dollars of defaulted syndicated bank loans were swapped into Brady Bonds. The Brady Plan jump-started the international market for developing countries' debt by launching 4 types of bonds: (i) Discount Bonds, (ii) Par Bonds, (iii) New Money, and (iv) Cash Buybacks. ${ }^{15}$

In the second half of the 1970s, sovereign international bonds represented about 7 percent of external public debt of developing countries owed to private creditors; by 2008, their share had increased to 67 percent (in Latin America, the share of bonded debt increased from a minimum of 9 percent to a peak of 82 percent). Over the same time period, the share of syndicated bank loans went from 70 to 25 percent of total private lending.

\footnotetext{
${ }^{15}$ Discounts were 30 year collateralized bonds (the collateral consisted of US Treasuries) with lower face value (about 30 to 35 percent less than the original claim), an interest rate of LIBOR plus 13/16, and a single (bullet) payment at maturity. Par bonds were similar to discounts but were issued at face value and had a fixed interest rate of 6 percent. With New Money, banks retained the full value of their claim but committed to issuing new loans amounting to at least 25 percent of the original claim. Cash Buybacks involved repurchases of the debt at a pre-established price.
} 
Since part of the interest and principal payment of Brady bonds was collateralized, country risk was usually calculated with "stripped" yields (where bonds were stripped of there collateralized component). While Brady Bonds played a key role in creating this new market, the calculation of stripped yield and the legal treatment of collateralized instrument were somewhat cumbersome and market participants expressed preference for the new Global Bonds issued after the Brady deals. Therefore, developing countries started retiring the old Brady's (even if some of them had expirations dates well in the 2020s) and substituting them with global bonds. By the end of the first decade of the new millennium there were hardly any Brady Bonds left in the market. 


\section{References}

Aguiar, Mark, and Gita Gopinath. 2006. "Defaultable Debt, Interest Rates and the Current Account.” Journal of International Economics, 69(1): 64-83.

Alesina, Alberto, Filipe Campante, and Guido Tabellini. 2008. "Why Fiscal Policy is Often Procyclical?” Journal of the European Economic Association, 6(5): 1006-1036

Amador, Manuel. 2003. “A Political Economy Model of Sovereign Debt Repayment.” http://www.stanford.com/ amador/debt.pdf

Benjamin, David, and Mark Wright. 2008. "Recovery before Redemption? A Theory of Delays in Sovereign Debt Renegotiations.” Unpublished.

Bi, Ran, Marcos Chamon and Jeromin Zettelmeyer. 2008. "The Problem that Wasn't: Collective Action Problems in Sovereign Debt Exchanges.” Unpublished.

Bolton, Patrick, and Olivier Jeanne. 2005.”Structuring and Restructuring Sovereign Debt: The Role of Seniority.” NBER Working Paper No. 11071.

Borensztein, Eduardo, Marcos Chamon, Olivier Jeanne, Paolo Mauro, Jeromin Zettelmeyer, 2005. "Sovereign Debt Structure for Crisis Prevention,"

IMF Occasional Papers 237, International Monetary Fund.

Eduardo Borensztein \& Paolo Mauro, 2004.

"The case for GDP-indexed bonds," Economic Policy, CEPR, CES, MSH, vol. 19(38), pages 165-216, 04.

Borensztein, Eduardo, Eduardo Levy Yeyati, and Ugo panizza Panizza, 2006, Living with Debt, Interamerican Development Bank and Harvard University Press

Bulow Jeremy, and Kenneth Rogoff. 1989a. "Sovereign Debt: Is to Forgive to Forget?" American Economic Review, 79(1): 43-50.

_. 1989b. “A Constant Recontracting Model of Sovereign Debt.” Journal of Political Economy, Vol. 97(1): 155-178.

Calvo, Guillermo, 2005, Emerging Capital Markets in Turmoil, MIT Press.

Catao, Luis, and Bennett Sutton. 2002. "Sovereign Defaults: The Role of Volatility.” IMF Working Paper 02/149.

Catao, Luis, Ana Fostel, and Sandeep Kapur. 2007. "Persistent Gaps, Volatility Types, and Default Traps." IMF Working Paper No. 07/148.

Catao, Luis, and Sandeep Kapur. 2006. "Volatility and the Debt-Intolerance Paradox." IMF Staff Papers, 53(2): 1-27.

Chowdhry, Bhagwan. 1991. "What Is Different about International Lending?” Review of Financial Studies, 4(1):. 121-148.

Christensen, Jakob. 2006. Special Data Section Domestic Debt Markets in Sub-Saharan Africa. IMF Staff Papers 52(3): 518-538. 
Cline, William R. 1984. International Debt: Systemic Risk and Policy Response. Washington: Institute of International Economics.

Cole, Harold L., and Patrick J. Kehoe. 1995. "The Role of Institutions in Reputation Models of Sovereign Debt.” Journal of Monetary Economics, 35(1): 46-64.

_. 1998. "Models of Sovereign Debt: Partial versus General Reputations.” International Economic Review, 39(1): 55-70.

Cowan, Kevin Eduardo Levy Yeyati, Ugo Panizza, and Federico Sturzenegger (CLYPS. Sovereign Debt in The Americas: New Data and Stylized Facts. IDB, Research Department Working Paper \#577

Cruces, Juan and Christoph Trebesch. 2010. "Pricing Haircuts: Do Markets Punish Low Recovery Values in Sovereign Restructurings?” unpublished UTDT

Detragiache, Enrica, and Antonio Spilimbergo. 2001. "Crises and Liquidity: Evidence and Interpretation.” IMF Working Paper 01/2.

Eaton, Jonathan. 1996. "Sovereign Debt, Reputation and Credit Terms.” International Journal of Finance \& Economics, 1(1): 25-35.

Eaton, Jonathan, and Mark Gersovitz. 1981. "Debt with Potential Repudiation: Theoretical and Empirical Analysis.” Review of Economic Studies, 48(2): 289-309.

—, and Joseph E. Stiglitz. 1986. “The Pure Theory of Country Risk.” European Economic Review, 30 (3): 481-513.

Eaton, Jonathan, and Raquel Fernandez. 1995. “Sovereign Debt.” In Handbook of International Economics, Vol. 3, ed. Gene M. Grossman and Kenneth Rogoff Amsterdam: North Holland.

Eichengreen, Barry J., and Richard Portes. 1995. Crisis? What Crisis? Orderly Workouts for Sovereign Debtors. London: Centre for Economic Policy Research.

Eichengreen, Barry, and Ricardo Hausmann. 1999. Exchange Rates and Financial Fragility. Paper presented at the symposium New Challenges for Monetary Policy, August 26-28, Jackson Hole, WY.

Eichengreen, Barry, and Ricardo Hausmann (2005) "The Road to Redemption" in B.

Eichengreen and R. Hausmann (eds.) Other People's Money, Chicago University Press

Eichengreen, Barry and Ricardo Hausmann \& Ugo Panizza, 2007. "Currency Mismatches, Debt Intolerance, and the Original Sin: Why They Are Not the Same and Why It Matters," in: Capital Controls and Capital Flows in Emerging Economies: Policies, Practices and Consequences, pages 121-170 National Bureau of Economic Research, Inc.

Eichengreen, Barry, Ricardo Hausmann and Ugo Panizza (2005) "The Mystery of Original Sin" in B. Eichengreen and R. Hausmann (eds.) Other People's Money, Chicago University Press

Eichengreen, Barry J., Kenneth M. Kletzer, and Ashoka Mody. 2003. "Crisis Resolution: Next Steps.” Brookings Trade Forum-2003: 279-337. 
Enderlein, Henrik, Laura Müller, and Christoph Trebesch. 2008. "Sovereign Debt Disputes. Testing the Role of Politics and Institutions in Financial Crisis Resolution.” Paper presented at the Political Economy of International Finance Workshop, Claremont McKenna College, Claremont CA.

Fernandez, Raquel, and Robert W. Rosenthal. 1990. "Strategic Models of Sovereign-Debt Renegotiations.” Review of Economic Studies, 57(3): 331-349.

Flandreau, Marc, Norbert Gaillard, and Ugo Panizza, 2010.

Gavin, Michael, and Roberto Perotti. 1997. "Fiscal Policy in Latin America.” NBER

Macroeconomics Annual, ed Ben Bernanke and Julio Rotemberg, 11-61. Cambridge MA:

MIT Press.

Grossman, Herschel I and Van Huyck, John B, 1988 "Sovereign Debt as a Contingent Claim: Excusable Default, Repudiation, and Reputation," American Economic Review, American Economic Association, vol. 78(5), pages 1088-97, December

Group of Ten. 1996. "The Resolution of Sovereign Liquidity Crises: A Report to the Ministers and Governors Prepared Under the Auspices of the Deputies.” http://www.bis.org/publ/other.htmGten.

Guscina, Anastasia and Olivier Jeanne, and. 2006. Government Debt in Emerging Market Countries: A New Data Set. IMF Working Paper no. 06/98. International Monetary Fund, Washington, DC.

Haldane, Andrew G., Adrian Penalver, Victoria Saporta and Hyun-Song Shin. 2004. “Analytics of Sovereign Debt Restructuring.” Journal of International Economics, 65(2): 315-333.

Hagan, Sean. 2005. "Designing a Legal Framework to Restructure Sovereign Debt.” Georgetown Journal of International Law, 36(.2): 299-403.

Hausmann, Ricardo (1999), “Should there be five currencies or 105?”, Foreign Policy (Fall).

Hausmann, Ricardo and Ugo Panizza (2010), "Redemption or abstinence? Original sin, currency mismatches and counter-cyclical policies in the new millennium", Centre for International Development at Harvard University, Working Paper No. 194, January.

International Monetary Fund. 2006. Applying the Debt Sustainability Framework for Low Income Countries Post Debt Relief. Mimeo, IMF

Jaimovich and Panizza (2009), "Public Debt around the World" Applied Economics Letters

Jeanne, Olivier 2004. “Debt Maturity and the International Financial Architecture,” IMF Working Paper 04/137.

Kletzer, Kenneth M. 1994. "Sovereign Immunity and International Lending.” In The Handbook of International Macroeconomics, ed. Rick. van der Ploeg. Oxford: Blackwell.

— , and Brian D. Wright. 2000. "Sovereign Debt as Intertemporal Barter.” American Economic Review, 90(3): 621-639.

Kohlscheen, Emanuel. 2005. “Sovereign Risk: Constitutions Rule.” The Warwick Economics Research Paper Series (TWERPS) 731, University of Warwick, Department of Economics. 
Krueger, Anne O. 2001. "International Financial Architecture for 2002: A New Approach to Sovereign Debt Restructuring.” Address given at the National Economists' Club Annual Members’ Dinner. (Washington DC: American Enterprise Institute.

Lanau, Sergi. 2008. “Sovereign Debt Restructuring,” Ph.D. Diss. Universitat Pompeu Fabra.

Levy Yeyati, Eduardo. Forthcoming. "Optimal Debt: On the Insurance Value of International Debt Flows to Developing Economies.” Open Economies Review.

Levy Yeyati and Panizza, forthcoming; "The Elusive Costs of Sovereing Default," Journla fo Development Economics

—, and Ugo Panizza. 2006. "The Elusive Costs of Sovereign Defaults,” ," IDB Research Department Working Paper No. 581.

Manasse, Paolo, Nouriel Roubini, and Axel Schimmelpfennig. 2003. "Predicting Sovereign Debt Crises.” IMF Working Paper 03/221.

McFadden, Daniel, Richard Eckaus, Gershon Feder, Vassilis Hajivassiliou, and Stephen O’Connell. 1985. "Is There Life After Debt? An Econometric Analysis of the Creditworthiness of Developing Countries." In International Debt and the Developing Countries, ed. by Gordon Smith and John Cuddington. Washington DC: The World Bank.

Mendoza, Enrique, G., and Vivian Z. Yue. 2008. "A Solution to the Default Risk-Business Cycle Disconnect.” NBER Working Paper No. 13861.

Ugo Panizza \& Federico Sturzenegger \& Jeromin Zettelmeyer, 2009.

"The Economics and Law of Sovereign Debt and Default," Journal of Economic Literature, American Economic Association, vol. 47(3), pages 651-98, September.

Pescatori, Andrea, and Amadou N. R. Sy. 2007. "Are Debt Crises Adequately Defined?," IMF Staff Papers, 54(2): 306-337.

Pitchford, Rohan and Mark Wright. 2007. "Restructuring the Sovereign Debt Restructuring Mechanism.” Unpublished.

Reinhart, Carmen and Kenneth Rogoff (2009) This Time is Different, Princeton University Press

Reinhart, Carmen, Kenneth Rogoff and Miguel A. Savastano. 2003. "Debt Intolerance.” Brookings Papers on Economic Activity, 34(1): 1-74.

Rochet, Jean Charles. 2006. “Optimal Sovereign Debt: An Analytical Approach.” IDB Research Department Working Paper No. 573.

Rogoff, Kenneth, and Jeromin Zettelmeyer. 2002. "Bankruptcy Procedures for Sovereigns: A History of Ideas, 1976-2001.” IMF Staff Papers, International Monetary Fund, 49(3): 470507.

Sachs, Jeffrey and Daniel Cohen. 1982. "LDC Borrowing with Default Risk." NBER Working Paper No. 925.

Sandleris, Guido. 2005. “Sovereign Defaults: Information, Investment and Credit.” Paper presented at the 2005 Meeting Papers 21, Society for Economic Dynamics. 
Sturzenegger, Federico and Jeromin Zettelmeyer. 2007a. Debt Defaults and Lessons from a Decade of Crises. Cambridge, MA: MIT Press.

Talvi, Ernesto, and Carlos Vegh. 2005. "Tax base variability and procyclical fiscal policy in developing countries.” Journal of Development Economics, 78(1):156-190.

Tomz, Michael and Mark Wright. 2007. “Do Countries Default in Bad Times?” Journal of the European Economic Association, 5(2): 352-60.

Tornell, Aaron, and Philip R. Lane. 1999. “The Voracity Effect.” American Economic Review, 89(1): 22-46.

Trebesch, Cristoph. 2008. "Delays in Sovereign Debt Restructurings. Should We Really Blame the Creditors?" Unpublished.

Van Rijckeghem, Caroline, and Beatrice Weder. 2004, “The Politics of Debt Crises.” CEPR Discussion Paper No. 4683.

Wright, Mark. 2002. “Reputations and Sovereign Debt.” Unpublished. 